\title{
Unfit for Subjection: Mental Illness, Mental Health, and the University Undercommons
}

\author{
Sarah Hankins
}

\section{[content warning: mental illness and references to ableism]}

I would like to call attention to what can be politely termed "a gap in the discourse" surrounding mental illness in the dominion of professional academia. Psychic struggle marks the common ground of much of our labor in the shadow of the ivory tower-a muddy paddock that has been thoroughly criss-crossed by the tracks of countless young idealists, dutiful strivers, weary cynics, and disenfranchised subjects. Follow any of one of these tracks from the point where it begins to wherever it stops, or in whichever direction it leads across this welltilled field, and see who you find along the way. Likely, you'll encounter more Black and Indigenous people of color, immigrants and international students than white Americans; more queer, trans, and nonbinary folks than cisgendered heterosexuals; more people with disabilities than those without; more women than men. Grad students, adjuncts and contingent faculty know this ground well, as do many of the workers who staff University departments, administrative offices, and facilities. The shifting and variegated topographies of psychic suffering are certainly not bound to the rigid logics of white supremacy, heteropatriarchy and capitalism, but their overlapping contours are clear on the map.

Mental illness is a profound dimension of lived experience for real people and real communities; it can wear our bodies down to the bone and grind away our collective energies for hope and conviction, planning and action. Despite the awkwardness of the term-and the glaring fact that it has been mobilized far too often in the name of policing difference- "mental illness" nudges us toward a dense and roiling center of gravity around which circulate our many discourses and practices of intersectional critique, always reflecting and refracting this core urgency, but rarely addressing it outright. I want us to be open to the possibilities of reclaiming "mental illness," not only as a term that cuts through respectability politics and gives plain voice to the dark landscapes, the terrible abysses of loneliness that so many of us have had to fight our way through in the name of academia-but also because I believe that mental illness marks a fertile terrain of 


\section{Current Musicology}

collectivity, a space for "otherwise possibilities" of thought, art and activism (Crawley 2017) that has yet to be fully explored.

If you want evidence that mental illness has the potential to organize radical communities and disrupt the implacable forward-march of the academicindustrial complex, look no further than its rhetorical alter ego, "mental health" - the proud star of discourse within the itself. Tell the University (personified, maybe, as the affable lout who is your Chancellor, or even the well-meaning chair of your tenure committee) that you're nervous about the possible ramifications of discussing mental illness in a respected academic publication, for an audience of your peers and senior colleagues. Far from pooh-poohing a junior faculty member who is in distress, the University will respond with all eagerness, and with reams of documents ready to hand. It will say:

We're so glad you came forward, and we understand your concerns! We here at University are committed to supporting the mental health and well-being of our whole campus community. We are a family. A family whose guiding principles are excellence, innovation, and collaboration. To that end, we're collaborating with local and state agencies and some fantastic private-sector partners to program a calendar of self-care and wellness events for students, faculty, and staff. This exciting new program builds upon our longstanding Campus Flourish Initiative, which, if you'll look here, has already exceeded our targets by a robust margin. What's more, we take this opportunity to remind you of the full menu of support services available through the Office of Counseling and Psychological Services, the Faculty and Staff Assistance Program, and the Optum Behavioral Health Network.

To be clear, the object of this essay is not a takedown of mental health infrastructures on college campuses (such as they are), nor of the difficult work that clinicians and counselors try to accomplish with us and for us. What I'm suggesting is that the discourse of mental health in the University-limned by positivist, individualizing rhetorics of "wellness," "self-care," "symptom management," and "adjustment" - gives little actual address to mental illness, which is an experience of psychic and bodily suffering that is always-already structured beyond the individual. On the other hand, I think this whole rhetorical accumulation very neatly effects a kind of neoliberal covering of tracks. The campus-wide initiative; the mental health awareness campaign; the administrative communique - these sturdy proofs of the University's humanism obscure the grinding, unrelenting precarity of its own systems of labor. They also obscure the dynamics of marginalization and contingency that operate along lines of race, gender, and class; which are everywhere intersected by the implacable logics of productivity and professionalization.

I have wondered whether the true telos of mental health in the discourse 


\section{Project Spectrum Colloquy}

of the University is not in fact the "healing" or redress of illness at all, but rather its instrumentalization. In my ten years of professional academia-as a grad student, then a wandering adjunct; now as junior faculty on the tenure trackI've learned to experience psychic suffering and the sicknesses of my body primarily as evidence that I'm not working hard enough; I'm not putting the hours in, or I'm putting them into the wrong task. My "self-care" looks like switching over to syllabus preparation or grading when I'm tired of editing my article draft. I've come to believe, quite sincerely, that my soul's peace is waiting for me at the end of my book manuscript.

This is biopower under the sign of neoliberalism: the administered equivalence of personhood with the production of value. In the closing of this sign, the body and the affects are expelled; they become its residue; its nonsalable material (Kristeva 1982; Robinson 1983). And I think this remainderwhatever of the self cannot be instrumentalized in service of production-is what we're really trying to get at, even if we can't recognize it, when we talk about "mental illness." We try. Except it's too late now for resignification: this dark material is insensible to discourse. It is mute, seething and abject. It can only huddle into itself, turn on itself-on ourselves-a collapsing, shriveling, festering, fading, which we might as well call anxiety, depression, loneliness, stress, chronic fatigue, migraine, insomnia, addiction, suicidal ideation.

Yet if we survive this return of the real, if we can bear to gather up these cast-off and "surplus" parts of ourselves-even though they are as heavy as lead, and we are so tired-we might discover that there is a place for us in the University after all, somewhere we can go and present ourselves, and give over our hands full of junk, and put our feet under the table. We thought that we were alone, but others are here already. In fact, they've been gathering for quite some time, wherever and whenever can. In an empty classroom, a grad student lounge, a coffee shop, a break-out session. They are studying instead of working, fashioning things out of junk, frittering away perfectly good knowledge, misappropriating University resources - worst of all, they are wasting their own potential. This one is a tenured queer theorist, writing poetry instead of journal articles. That one is an adjunct lecturer in biochemistry, using her library privileges to check out stacks of young adult novels and books on decolonial pedagogy. Here is a $\mathrm{PhD}$ candidate in musicology who convinced her department to fund an affinity group for students of color. Here's a TA who organized a walkout; another TA who had to walk out of class so that his students wouldn't see him cry.

This band of brigands does not claim a departmental affiliation, a job title, 


\section{Current Musicology}

a Center for Brigandry Studies; but many who gather have been grateful to accept the name of Undercommons, which is a gift that has come down to us through the labors of Black studies, queer of color critique, Black radicalism and Afropessimism. Importantly, neither that name nor that tradition give any special call to "mental illness." Certainly, they do not credit any theoretical status to the lexicon of depression, anxiety, dysphoria, etcetera. Moreover, the Undercommons does not, cannot offer redress, relief, restoration to a state of wholeness, or any "fixing" of the self that might be recognized by the University, or by psychology or medicine. The ontology of the Undercommons is dispossession; its knowledge is that of the shipped, and the broken being; its praxis is breaking, undoing and unmaking - not building up, but tearing down (Harney and Moten 2013). So, if I should turn to the Undercommons in pain, with my need as my petition, am I therefore-to paraphrase Fred Motencoming under false pretenses, bringing bad documents?

It could be so. And yet, in the Undercommons' refusal to answer the "call to order," its "dumb insolence" in the face of University's demand, we might hear a response to a different mode of address: the inchoate desperation of the denizens of the "academy of misery" (Harney and Moten 2013). We make a great hue and cry, but at the core of our thousand legitimate grievances is a single, abyssal utterance: I am unfit. And the Undercommons gives nothing so paltry as an answer, but simply replies: We agree.

The we is important here. Whenever, wherever the Undercommons takes place or shape-in a piece of writing, an instance of discourse, in the tone of a conversation, at a gathering of persons-there's always some presence of we, of us. An energy of plurality, let's say; a multiplicity that flows, eroding the petrified singularity. Of course, we'd best not come looking for warm fuzzies. The Undercommons are not concerned to legitimate my grievances, accept my apologies, or affirm the goddess within. As Moten puts it: "This coalition emerges out of your recognition that it's fucked up for you, in the same way that we've already recognized that it's fucked up for us. I don't need your help. I just need you to recognize that this shit is killing you, too, however much more softly, you stupid motherfucker, you know?" $(2013,10)$.

But that's the thing: a stupid motherfucker is a different animal than a head-case. If she can get unbound from the toxic isolation of her self, give up on that sexy pretty promise-that robust selfhood, that "mental health" which is only the detritus of the subjugating positivism of the University-a stupid motherfucker might find her private depressions, her secret fears and anxieties, her panic transformed into collective practices of disidentification and fugitivity, 


\section{Project Spectrum Colloquy}

disruptive collaboration, mutuality, and debt (Muñoz 1999; Hartman 2002; Spillers et. al., 2007; Halberstam 2011; Harney and Moten 2013).

Approaching mental illness by way of the Undercommons-or maybe I'm offering mental illness to the Undercommons?-does not mean eliding the particularities of psychic suffering that the academy of misery constructs for every subject, every self, and which it mobilizes as labor in the service of its production. Nor does this approach deny how these struggles are viciously reproduced and endlessly recontoured by blackness, brownness, queerness, disability, femininity, economy, geography, language, religion. Quite the opposite. That which is reified and pathologized as "mental illness" in the discourse of the University is exposed, by the light of the Undercommons, as the marks of structural violence on our bodies and psyches. And if, as Moten and Harney propose, the ethical project of the Undercommons is to remain "unfit for subjection," unreliable and obstructionist and unproductive in the face of the unremitting demands of the University, then surely we who are ill-stressed and depressed, fatigued, disappointed, and denied—can find a welcome here.

\section{References}

Crawley, Ashon T. 2017. Blackpentecostal Breath: The Aesthetics of Possibility. New York: Fordham University Press.

Halberstam, Jack. 2011. The Queer Art of Failure. Durham, NC: Duke University Press. Hartman, Saidiya. 2002. “The Time of Slavery”. The South Atlantic Quarterly 101 (4): $757-$ 776.

Harney, Stefano and Fred Moten. 2013. The Undercommons: Fugitive Planning and Black Study. New York: Minor Compositions.

Kristeva, Julia. 1982. Powers of Horror: An Essay on Abjection. Translated by Leon S. Roudiez. Columbia University Press.

Moten, Fred. 2017. Black and Blur: Consent Not to Be A Single Being. Durham, NC: Duke University Press.

Muñoz, José Esteban. 1999. Disidentifications: Queers of Color and the Performance of Politics. University of Minnesota Press.

Robinson, Cedric. 1983. Black Marxism: The Making of the Black Radical Tradition. Chapel Hill: University of North Carolina Press.

Spillers, Hortense J, et al. 2007. “'Whatcha Gonna Do?": Revisiting 'Mama's Baby, Papa's Maybe: An American Grammar Book': A Conversation with Hortense Spillers, Saidiya Hartman, Farah Jasmine Griffin, Shelly Eversley, \& Jennifer L. Morgan.” Women's Studies Quarterly 35 (1/2): 299-309. 